\title{
SOCIAL PROBLEMS IN GLOBAL MIGRATION: THE CASE OF TRNC
}

\author{
PROBLEMAS SOCIALES EN LA MIGRACIÓN GLOBAL: EL CASO DE TRNC
}

PROBLEMAS SOCIAIS NA MIGRAÇÃO GLOBAL: O CASO DO TRNC

\author{
Sinem Kasimoğlu \\ Near East University - Turkey
}

Resumo: O objetivo do estudo é investigar as consequências negativas da imigração, embora todos os migrantes sonhem com melhores condições para outras geografias. No contexto da migração global, os problemas sociais são tratados no contexto da República Turca do Norte de Chipre. Sabe-se que o impacto da imigração na vida social é sentido de maneira mais rápida e clara nos modelos urbanos calmos e com funcionamento lento. Nesse sentido, o norte de Chipre está passando por uma mudança significativa, especialmente na migração do Oriente Médio, da Península Arábica e da África. Em populações de pequena escala, como o TRNC, é possível eliminar as desvantagens sociais, econômicas e políticas das migrações.

Palavras-chave: migrações, Chipre do Norte, desvantagens das migrações

\begin{abstract}
Of the goal of study is to investigate the negative consequences of immigration, although all migrants dreams of better conditions to other geographies.. In the context of global migration, social problems are handled in the context of the Turkish Republic of Northern Cyprus. It is known that the impact of immigration on social life is felt faster and more clearly in the calm and slowly functioning urban models. In this sense, Northern Cyprus is experiencing a significant change, especially in the migration from the Middle East, the Arabian Peninsula, and Africa. In small-scale populations such as the TRNC, it is possible to eliminate the social, economic, and political disadvantages of migrations.
\end{abstract}

Key words: migrations, Northern Cyprus, disadvantages of migrations

Resumen: El objetivo del estudio es investigar las consecuencias negativas de la inmigración, aunque todos los migrantes sueñan con mejores condiciones para otras geografías. En el contexto de la migración global, los problemas sociales se manejan en el contexto de la República Turca del Norte de Chipre. Se sabe que el impacto de la inmigración en la vida social 
se siente más rápido y más claramente en los modelos urbanos tranquilos y de funcionamiento lento. En este sentido, el norte de Chipre está experimentando un cambio significativo, especialmente en la migración desde el Medio Oriente, la Península Arábiga y África. En poblaciones de pequeña escala como el TRNC, es posible eliminar las desventajas sociales, económicas y políticas de las migraciones.

Palabras clave: migraciones, norte de Chipre, desventajas de las migraciones

\section{Introduction}

The phenomenon of migration is a significant problem affecting all the countries of the world today. According to the 2018 World Migration Report of the Migration Research Foundation (2018), the number of international migrants has increased significantly over the last 45 years. This number, which was 84 million in 1970, reached 153 million in 1990 and 244 million in 2015. This number of international migrants points to the fact that one in every 30 people is an immigrant. Most of Europe and Asia continents are home to the people who are not happy in their lands. In this sense, $62 \%$ of the world's immigrant population preferred countries in Europe and Asia. The country that received the most immigration was the United States of America, which received 12 million in 1970 and 46.6 million in 2015. With more than 12 million immigrants in Germany, it is the second country to receive the most immigration.

In terms of international law, the concepts of de refugee, and" immigrant "are defined as follows: Refugee; It is a person who has a rightful fear that he will be persecuted because of his race, religion, nationality, membership of a particular social group or his political ideas, and therefore he who has left his country and cannot return or does not want to return due to his fear. Migrants; persons who migrate to another country legally or illegally and who reside outside of their permission or with the consent of the relevant authorities. In this case, almost all of the foreigners living in Northern Cyprus are in the in Migrant yaşayan category. (Dolunay ve Keçeci, 2017).

As far as the concepts of Refugees and Immigrants are concerned in terms of TRNC Law (Chapter 105); any person who is allowed to enter Cyprus or reside in Cyprus after 3 September 1939, for humanitarian reasons and with an extraordinary regulation, in compliance with immigration laws. However, it does not include anyone who is permanently married to someone calm in Cyprus. The immigrant describes a foreigner who enters the Turkish Republic of Northern Cyprus in the Turkish Republic of Northern Cyprus for permanent and permanent 
residence (Külahc1, 2017). Migration; population movements carried out from one region to another, either individually or collectively, for purposes of work, and for training and/or living purposes. (Erkan ve Erdoğdu, 2006, s. 81; Bulut ve Eraldemir, 2015, s. 16).

Migration is qualitatively divided into two groups; ) Forced migration and" voluntary movement (Aksoy, 2012: 293). Some serious unrest, conflict, civil war, and so on. They are (escaping $\mathrm{v}$ in cases where they feel safe and suspicion of life security, and they migrate to another region they see as safe within their country or to another state where they see it as safe (Erkan and Erdoğdu, 2006, p. 109); Migration can be called as voluntary migration (Gol \& Miller, 2008: 11) in order to achieve better living conditions than just the economically existing life conditions (Castles \& Miller, 2008: 11) without such vital matters (Tunç, 2015, p. 31; , et al., 2016, p. 3).

When the population movements in the TRNC are examined, it is seen that the phenomenon of migration is not necessarily but voluntary. The concept of voluntary migration, which does not include the conditions of forced migration, coincides with the TRNC. Im. The number of people coming to TRNC for training purposes is quite high. According to March 2019 Population Registration Office data; The population of the TRNC is 374 thousand 299 people. While the citizens of the TRNC are 250 thousand 497 people, the number of people in the country with valid leave is 121 thousand 802 . With the permission of the students, there are 59 thousand 482 people in the country. Almost 20 percent of the population is composed of people who are on the island with the permission of the student, while the families of these persons are also legal with the legal process such as residence and work permit.

As the fundamental theories defining migration, theories of "push" and "pull Göç are accepted. In this context, the characteristics of the place to emigrate are ülen removing ülen individuals; the features of the home 2008 push s individuals (Öztürk and Altuntepe, 2008, p. 1590). Individuals migrate and feel that they will not feel safe where they are located and where the destination will be more secure for them and their families, or where their location is more inadequate in terms of working opportunities (economic opportunities) and where the destination will be more efficient in terms of these opportunities. The migrant is one of the migration mentioned above movements (voluntary or compulsory within the scope of internal migration, optional or mandatory within the range of external migration) and is the general name given to the individuals and groups (Kara and Korkut, 2010, p. 154).

The characteristics of the location of the people pushing people, the properties of the thought of people to create a gravitational force, the TRNC can be handled differently. While 
people coming from outside find the characteristics of the country attractive, this may not be valid for the country people. It is seen that especially the young population experienced a migration movement due to reasons such as political and economic embargo, limitation of career opportunities, desire to live in more modern society, cumbersome state and bureaucracy. The number of Cypriots settled in countries such as England, Germany, Australia, Canada, etc. due to reasons such as lack of job opportunities in the area where they receive education and the presence of social and economic insecurity is not at all small. Most of the young people who have completed their higher education abroad do not want to return to Ada. In this sense, TRNC, which is in an attractive position by the citizens of different countries, can lose its charm for the citizens of the country.

\section{Trnc And Transmission Problem}

Turkish citizens who migrated to the Turkish Republic of Northern Cyprus (TRNC) after years of internal and external migration were divided into three groups. Accordingly, the first group consists of individuals and their families who are actively involved in the 1974 Peace Operation and are therefore given the right to settle in Cyprus; The second group consists of migrants who have been controlled in order to eliminate the population gap after the Peace Operation; The third group consists of individuals who settle on the island by migrating for economic reasons with the aim of establishing a new life (Şahin, 2001).

1. Those who enter the TRNC illegally:

2. Those who do not leave the TRNC while they enter TRNC in a legal way but do not leave the TRNC: If deemed necessary, they must be deported but in practice they are not deported. If they pay the visa penalties, they do not apply for issuance.

3. While entering the TRNC through legal means, those who violate the entry permit: In particular, they come with a tourist visa and inform the employees about unregistered employment. Students come and work in a variety of jobs except students.

Migration, a phenomenon that has the potential to affect almost everything human and human, reveals a process that needs to be addressed in different aspects of history. The course of migration with the factors that cause migration is the determinant of the effects of migration. Immigration is a phenomenon that needs to be examined in different aspects, and if it is not foreseen, then it is a phenomenon that has the potential to lay the groundwork for many problems that it is not possible to overcome later. However, the phenomenon of migration, 
which has different components and has a multidimensional effect, is approached as a phenomenon related to social policy in many countries (Borjas, 1994, p. 1714). the fact that it is only processed in this dimension remains valid for some countries. It is possible to observe the change in social life in the case of an island country, TRNC, which has not yet begun to come with large waves, but which is influential to the social life compared to the low population. official in the country 30 universities and nearly half of the 103 thousand students studying in these universities, Turkey, comes from the Middle East, Arab countries and African countries. The fact that some of the students come with their families and settle in the country legally or illegally causes an important change for an island with an official population of 350 thousand. In the researches, it is seen that the local migrants of Northern Cyprus have been negatively affected by the foreign migrations they have observed closely for the last 10 years. Due to the positive living conditions of the TRNC and the unfavorable living conditions of the country, it does not meet the criteria of known immigration, either legally or illegally. The economic conditions of the TRNC, which is an island country with a population of close to 400 thousand, are not naturally concentrated in a large population density. Migrants who work with less wages and mostly informally, have to live in poor quality life conditions and cause loss of local labor. The negative living conditions of the immigrants have negative effects on social and cultural integration and bring about the incompatibility of the rules of society. In fact, it is observed that the judicial issues involving foreigners increased parallel to the population of migration.

According to the Turkish Cypriot Chamber of Commerce's "TRNC Informal Economy Report diş in 2015, it is stated that one out of every five working people is unregistered. According to 2011 figures, the tax and social security losses created by these individuals are 199 million TL.

According to the report prepared according to the 2018 audits of the Labor Office; one out of every three foreign workers is a foreigner. Republic of Northern Cyprus and Turkey that identifies the individuals who are nationals except for citizens 3. If, since 2005, a leak was detected operating rate of $10 \%$. The report also shows that there has been a steady increase in the rate of foreign illegal working after 2007 and that this ratio has reached $17 \%$ as of the end of 2011. Increased population and unregistered workplaces lead to unhealthy living conditions, which in turn leads to increased demand for health and inadequate state hospitals to meet this need from time to time. 
According to the Police Press Officer data, in 2017, a total of 469 crimes were committed in the cases of manslaughter, theft and arson, and 358 people were detained for the crimes. According to the data, the highest number of burglaries in the country. When the nationalities of the crimes related to the theft are examined, it is seen that there are 132 persons from TRNC, 129 people from TC, 8 persons from TRNC-TC and 270 persons from third countries. The number of third-country nationals arrested for theft in the country; 17 people from Nigeria; 1 person from Georgia, Palestine, Guinea, Jordan, Israel, Flipins, Iran, Saudi Arabia, Poland and Egypt; 2 people from Tajikistan, Ukraine, Lebanon, Morocco, USA and Bulgaria; 3 people from Azerbaijan; 4 people from Russia, Syria, Bangladesh, and Pakistan; 6 people from Turkmenistan, Zimbbave and England were identified as (http://www.yeniduzen.com/neler-oluyor-97692h.htm)

\section{The Effect Of Migrant Migrants To The Trnc}

The concept of migrant workers is divided into two sub-headings. Migrant workers in the first group; they work in one country to another country and often go with their families for long-term residence and fulfill the legal conditions of the country they go to and are entitled to long-term residence and may even obtain citizenship in that country. The second group of migrant workers; again, migrants who work in a certain country in order to work from one country to another, but who do not have a permanent residence purpose, and who work in certain jobs in the framework of the rules of the country they migrate, taking time work permit (Civan and Gökalp, 2011, p. 236).

Labor and Social Security Minister Zeki O Show, in an interview to the press in April 2018, is 104 thousand private sector employees in the country, noting that it is composed of people from the $40 \%$ Turkey, without coming work permit with a tourist visa working people that stated. "Unfortunately, to work in Turkey, our incoming laborers brother to earn one, we talk the same language, they do not work they have to be licensed and are trying to come up with a tourist visa. After any occupational accident, we can not we be involved in helping them both, and If we lose their lives, we are not obliged to look after their families, this information should be more in order to prevent this informality, we need to take a serious step to make this information more important in order for our brothers who work there to work more healthily. number, ie 104 thousand 10-14 thousand informal employees are available, "said Minister Celer, this is a" human drama "underlines the fact that. $t$ is. In the TRNC where almost every 
two of the foreign employees are registered, the tax and social security records are expressed in very high numbers. The immigrants working in the informal sector suffer a lot of damage to the country. Informal study; it raises the demand for health and education and increases the crime rates in the country; The increase in the number of crimes and convicts committed increases the occupancy rate of prisons, and the subject of prisons, which cannot meet the need, often finds its place in the media.

\section{Improvement Of Immigrants To Social Life}

One of the biggest problems experienced by migrants is the cultural differences. The immigrants, who try to live in the country they live in, try to maintain their country's culture and cultural behavior and habits. Starting in the 1960s and is considered one of the world's largest and legal migration "Turkey-Germany Workers' Hotline" cultural differences is one of the most important examples in the reflection of social life. The religious beliefs, developmental levels, educational levels and cultural structure of these two countries included great differences. which has the same continent, Germany and Turkey example of such a consideration knocks, Africa and migrated to places such as the Far East, different religions, languages and beliefs contained these individuals, cultural sense an audience to live seamlessly they have no common direction, it is not natural as possible. Nigeria, which is the country that sent the most students to the TRNC, is a good example of these cultural differences. Middle East countries and Africa countries are followed by Iraq. It is noteworthy that these students experience cultural problems rather than religious problems in the TRNC and they are in an effort to move their cultural values to the TRNC. For example; In TRNC, where there is a more civilized and appropriate traffic compared to many other countries, there are some difficulties in the traffic in recent years. Due to reasons such as not knowing the traffic rules, not being able to adapt, and not respecting the pedestrians and other drivers, serious problems may occur in country traffic.

In the country, the number of people working in sectors such as infant and elderly care, house cleaning, construction and services is also noteworthy. In particular, Turkey, Turkmenistan, Philippines, Pakistan, Moldova, Ukraine and foreign labor from countries such as Bangladesh, has increased over the years. According to the 2017 reports of Directorate of Labor; Approximately 57 thousand people from 126 countries came to work in the TRNC. Turkey, Turkmenistan and Pakistan on the list of the first three places share is noted in many 
different countries. Working with the permission of the labor, then the families of the migrant living with them by the side of the country, living in the country is trying to maintain their own customs and traditions. These people who do not fully adapt to the characteristics of the country they live in, establish a life within their cultural values, are not easily accepted by the people of the country.

In the TRNC, where there is a lack of modern migration and integration policy, the problems arising from the lifestyle in particular are a particularly striking issue. When the problems of African, Middle Eastern and Arabic students are examined; the fact that the home owners do not want to rent houses for Arab and African students, the students who are forced to work unregistered because of the economic difficulties do not benefit from the insurance and social rights, and they earn much less wages than the other employees, are the first problems.

\section{Conclusion And Recommendations}

When we look at the history of the island of Cyprus, which is home to many civilizations, we can see that it has been faced with various migrations for centuries. The process started in 1878 on the island being rented to the British Empire moved from under the Ottoman Empire, many Turkish Cypriots, mainly Turkey and the UK, Canada, USA, emigrated to countries such as Australia. It is known that the immigration to England and especially London has increased especially after 1960. Development of the land belonging to the Turks after 1974 and to the economic development of the newly established state of Turkey "agricultural labor" as the family were sent to the island.

When we look at the last 20 years, the profile of migration has changed considerably. People who come to the island with the desire of education, economy and a better life opportunities do not return to their country and settle here. The fact that the young people who come for educational purposes, with the permission of marriage or work permit on the Island and bring their families with them, is a reality of the TRNC. This island country, which does not have a large population, is experiencing some difficulties with such migration movements. In this geography where cultural and vital differences are felt in daily life, the values and judgments brought by the indigenous people from past to present change from time to time.

The increase in crime rates in the country compared to the past, the problems experienced in the island known for calm and tranquility, the country also makes the citizens uncomfortable, longing for the past. There are also measures to be taken for the peace of the 
society in this new cultural order, which consists of people from more than 100 countries and who come to the island with the hope of a better life from different countries. Particularly, it is very important to pay attention to hygiene and environmental cleanliness in the regions where immigrants are heavily located. It is very necessary to provide municipal services more intensively in these regions, to help and to provide support to economically disadvantaged people. The steps of eliminating cultural and social differences between the immigrant population and the indigenous population, ensuring that the immigrants know and recognize the culture of the country, the unregistered employment of the state by taking control of tax loss of the state should be taken immediately.

The coexistence of the individuals in the multicultural societies in peace, recalls the idea of tolerance. In the family, school and social life, empathy among the members of society can be added to the process of communication. Kuçuradi (1995) discusses the concept of tolerance at individual and community levels. Tolerance at the individual level; whether the individual is tolerant of human relations; the tolerant individual regards other individuals as their own, and respects the rights of other individuals even when they think differently; If the individual is intolerant, he / she does not respect, accept or even harm other people. Tolerance at community level; the attitude of the group or minority in the administration to the ideas and practices other than their own approvals and approvals; it manifests itself in society-based regulations and in the formation of the legal order.

It should not be overlooked that tolerance training can be given more effectively and permanently through properly structured communication processes, based on the idea that human beings exist with communication. It should not be forgotten that the idea of tolerance through education and communication that intensively interacts with each other will also affect the size of family, school and society. Providing trainings on the right communication with tolerance training in schools; and develop and support a pluralistic, multicultural and democratic society. (Dursun-Bilgin, Çelik and Kasımoğlu, 2018).

From this point of view, it is a process that can be achieved through education, to achieve cultural rapprochement, tolerance, to place the idea of tolerance in minds and to change the way of thinking. Education in the family can benefit when supported by school and community. 


\section{REFERENCES}

1. Aksoy, Z. (2012). Uluslararası göç ve kültürel değişim. Uluslararası Sosyal AraştırmalarDergisi, 5(20), ss. 292-303.

2. Borjas, G. J. (1994). The economics of immigration. Journal of Economic Literature 32 (4),pp. 1667-1717.

3. Bulut, Y. \& Eraldemir, Z. (2015). Göç olgusunun farklı boyutlarıyla Hatay ili İskenderun ve Dörtyol ilçeleri ölçeğinde incelenmesi, Uluslararası göç ve mülteci sorunun çözümünde kamu yönetiminin rolü paneli içinde. İstanbul: Umuttepe Yayınları. 13-38.

4. Castles, S. \& Miller, J.M. (2008). Göçler çă̆l, modern dünyada uluslararası göç hareketleri. İstanbul: Bilgi Üniversitesi Yayınları.

5. Civan, E.O. \& Gökalp, A. (2011). Göçmen işçi kavramı ve göçmen işçilerin iş sağlı̆̆ ve güvenliği. Çalışma ve Toplum, 1. ss. 233-264.

6. Dolunay, A. \& Keçeci, G. (2017).Göçmenlerin kent dokusuna etkisi: KKTC Surlariçi örneği. Tarih Kültür ve Sanat Araştırmaları Dergisi, 6(3), ss. 524-559.

7. Dursun-Bilgin, M., Çelik,M.U. \&Kasımoğlu, S. (2018). The role of communication in tolerance education. Quality \& Quantity, 52(2). pp. 1179-1186.

8. Erkan, R. \& Erdoğdu, Y. M. (2006). Göç ve Çocuk Suçluluğu. Aile ve Toplum. Göç Araştırmaları Vakfi. (2018). 2018 Dünya göç raporu 8, 3(9). ss. 79-90. http://gocvakfi.org/2018-dunya-goc-raporu/ (Erişim Tarihi: 20.04.2019).

9. Gündem Kıbrıs. (2018). KKTC vatandaşları kayıt dışı istihdamın \%48'ini oluşturuyor. https://www.gundemkibris.com/kibris/kktc-vatandaslari-kayit-disi-istihdamin-48iniolusturuyor-h243973.html (Erişim Tarihi:19.04.2019).

10. Kara, P. \& Korkut, R. (2010). Türkiye'de göç, iltica ve mülteciler. Türk İdare Dergisi, 467. ss. 153-162.

11. Kıbrıs Postası Gazetesi. (2019). İçişleri Bakanı Baybars: Ülkenin toplam nüfusu 374 bin 299. http://www.kibrispostasi.com/c35-KIBRIS_HABERLERI/n280494icisleri-bakani-baybars-ulkenin-toplam-nufusu-374-bin-299-26 (Erişim Tarihi: 18.04.2019).

12. Kuzey Kıbrıs Türk Cumhuriyeti'nde Kayıt Dışı Ekonomi ; Boyutlarının Ölçümü, Çözüm Önerileri ve Eylem Planı . Kıbrıs Türk Ticaret Odası Yayını (2019). https://www.researchgate.net/... Kayitdisi_Ekonomi...Cyprus.../Kayitdisi-EkonomiShado (ErişimTarihi: 10.04.2019).

13. Kuçuradi, I. (1995). Hoşgörü: Kavramı ve sınırları. Hoşgörü ve eğitim içinde. Editör: Bekir ONUR. Ankara: TürkEğitim Derneği. ss. 18-36.

14. Külahçı, Ş. (2017). Kktc'de mülteci ve göç hareketleri. 1. Uluslararası Doğal Afetler Konferansı'nda sunulan sözel bildiri. KKTC Sivil Savunma Teşkilatı. Lefkoşa.

15. Şahin, C. (2001). Yurt dışı göçün bireyin psikolojik sağlı̆̆ üzerindeki etkisine ilişkin kuramsal bir inceleme. Gazi Üniversitesi Eğitim Fakültesi Dergisi, 21(2). ss. 5767.

16. Tunç, Ş.A. (2015). Mülteci davranışı ve toplumsal etkileri: Türkiye'deki Suriyelilere ilişkin bir değerlendirme. Tesam Akademi Dergisi, 2(2). ss. 29-63.

17. Öztürk, M. \& Altuntepe, N. (2008). Türkiye'de kentsel alanlara göç edenlerin kent ve çalışma hayatına uyum durumları: Bir alan araştırması. Yaşar Üniversitesi Dergisi, 3(11). ss. 1587-1625.

18. Yakınthou, C. \& Polili, Ö. (2010). Ortak bir amaç üzerinden uzlaşmak: Kıbrıs'ta mülteci ve sı̆̆ınmacılar için insan hakları. İstanbul: Tesev Yayınları. 
19. Yeni Bakış Gazetesi. (2018). 2 yabancl çalışandan l'i kaçak. http://www.yenibakisgazetesi.com/2-yabanci-calisandan-1-i-kacak/30665/ (Erişim Tarihi: 19.04.2019).

20. Yeni Düzen Gazetesi. (2018).Neler oluyor? http://www.yeniduzen.com/neleroluyor-97692h.htm adresinden, (Erişim Tarihi: 20.04.2019).

21. Yeni Düzen Gazetesi. (2019). Kuzey Kıbrls mülteci gerçeği. http://www.yeniduzen.com/kuzey-kibris-multeci-gercegi-112147h.htm (Erişim Tarihi: 20.04.2019).

\section{SOBRE O AUTOR:}

\section{Sinem Kasimoğlu}

Assistant Professor ; Near East University, Near East Boulevard, 99138, Nicosia, Northern Cyprus, Via Mersin 10, Turkey. E-mail: sinem.kasimoglu@neu.edu.tr

http://orcid.org/0000-0002-2444-4314

Recebido em: 29 de outubro de 2019 Aprovado em: 10 de novembro de 2019 Publicado em: 25 de novembro de 2019 